\title{
Animal Representation on UK Children's Television
}

\author{
LYNDA M. KORIMBOCCUS, Independent Scholar
}

\section{ABSTRACT}

It is widely accepted that television is a powerful medium and that its influence, particularly on children and young people, can be profound (see for example Canadian Paediatric Society 2003; Strasburger 2004; Matyjas 2015). The representation and categorisation of non-humans in such content may therefore influence a culture's attitudes towards those species and, by extension, its children's views. This article investigates animal characters on three hundred and fourteen children's TV shows across five days of 'free' to view UK programming during summer 2020, and is the first study in over twenty-five years (since Elizabeth Paul's in 1996) to focus specifically on mainstream children's TV, and the only one to have sole regard for pre- and early primary-age UK viewers. With research clear that the media is so influential, recognising the role of such culture transmission is vital to 'undo' unhelpful assumptions about animals that result in their exploitation, and change future norms (Joy 2009). Television media either ignores or misrepresents the subjective reality of many (particularly food) species, but with children preferring anthropomorphised animals to most others (Geerdts, Van de Walle and LoBue 2016), this carries implications in terms of responsibility for our ideas and subsequent treatment of those non-humans in everyday life.

\section{KEYWORDS}

Animals, Children's Television, Representation, Characters, Anthropomorphic

\section{Introduction}

It surely escapes no-one's attention that a huge number of characters in children's animations are non-human animals of one species or another. Whether Peppa Pig or Peter Rabbit, the animality of these creature characters is clear, at least in general two-dimensional form. However, a huge volume of consumers of these children's animal characters are also consumers of animal flesh. This paradox is an oddity that seems to lose no power with the passage of time (see Bowd 1982). Why does the UK say it is an animal-loving nation at the same time as eating millions of them every year? Why are there parliamentary calls to ban the consumption of dog meat (Ares and Sutherland 2019) but not meat from cows or chickens? Why do so many caregivers of Peppa Pig fans feed them ham, bacon or sausages? The answers are multiple, but simple. We are raised from childhood to categorise some species as edible, others wearable, others companionable (Joy 2009). Anthropomorphism in representations of animals to children through mass media distorts the reality of a species and contributes to inaccurate beliefs (Grasso et al. 2020), particularly in animation, where boundaries are further blurred to maintain children's empathetic connections with the characters (Wells 2010). Add to this our penchant for denialism (Almiron 2020) even when the species is explicitly claimed as edible, and it is easier to strategically ignore the horrors of animal death and carcass processing, purchase shrink-wrapped body parts and maintain a blissfully ignorant status quo. 
This article highlights examples of these animal categorisations and (mis)representations as evidence of the transmission of such norm maintenance presented to children through TV programmes, their characters and storylines.

I should note in advance my employment of the terms 'animals', 'non-humans' and similar, used interchangeably throughout this piece, with 'animals' used most frequently due to its accessibility. This should not be taken to indicate any anthropodenial (Mills 2017) - that is, a failure to acknowledge humans as animals, nor animals as persons.

\section{British Children's Television}

My childhood Saturday evenings were spent either at home or at my grandparents', and were always 'family time'. Sitting with my sister and the rest of the family in the living room with our supper, watching whatever show was that season's highlight of family entertainment on BBC One, BBC Two or ITV - the only three channels available in the UK at that time. Despite the multitude of alternative media on offer now, it is still the case that many families sit together for a collective live TV entertainment experience at this time of the week (Cole and Stewart 2018). These days, instead of the Eighties favourite The Cannon and Ball Show, it might be the latest instalment of Strictly Come Dancing, The Masked Singer or a long-running family quiz show such as Family Fortunes. Live TV channels remain more popular and well-known than others in the UK, though streaming service Netflix does make the top five providers, alongside BBC One and ITV, with Channel 4 in first place (YouGov 2018). For children today, it may be inconceivable to imagine a time with only a few terrestrial TV channels, when recording something required a VHS machine and clunky cassettes, and when live streams related only to running water. But as far back as 1946 and Children's Hour star Muffin the Mule (BBC 2021a), TV has always sought to capture children's imagination, and animals have often been the way to do so.

By the 1990s, animals took up significant airtime in children's television programming, though these were part of a daily children's schedule rather than dedicated channels in and of themselves. Now in the 2020s, children's programming remains thus in some instances (Channel 5's Milkshake!, for example), but the addition of full channels devoted to children means they have more choice than ever before. Add to this the availability of online media for children, and the array can feel overwhelming for those of us who recall three-channel TV, and who were seldom given charge of the choice of viewing.

It wasn't until the mid- to late-2000s that use of the Internet was widespread, or that handheld digital devices such as tablets were found in the UK's 'basket of goods' (a measurement of an item's widespread popularity from the Consumer Price Index (CPI) until 2012 (Office of National Statistics 2016)). Though children's access to media is changing (Childwise 2020), significant numbers still watch live television regularly, particularly pre-schoolers, though this has declined as technology has advanced. For example, CBeebies' 0-3-year-old audience has dropped $16 \%$ to $40 \%$ in the last decade, reaching $37 \%$ of $4-6$-year-olds compared to $45 \%$ in 2010 (Ofcom 2020). However, many of the alternative means of accessing television are simply video links to programmes already shown on the live television channels, for example through 
BBC iPlayer streaming or the four CBeebies apps (Ofcom 2019). Whilst CBeebies has been the most popular dedicated television station for younger children up to six years old (Children's Media Foundation 2013), many prefer to watch programmes 'on demand' (Ofcom 2019).

Categorisation of animals into subject/object and edible/inedible takes place in the socialisation process (Stewart and Cole 2009), where social norms are instilled in toddlers before they are cognitively able to logically question them. The normative values associated with different species result in what we are taught to know, or not know, about them, and thereafter feeds directly into beliefs about what certain animals are 'for' (Joy 2009).

Whilst there already exist many comprehensive studies into cultural media representations of the non-human in books, movies or on television (see for example Molloy 2011; Ratelle 2015; Geerdts, Van de Walle and LoBue 2016; Mills 2017; Cole and Stewart 2018 and Stanton 2021), little research since Paul (1996) concentrates fully on the representation of non-humans on mainstream UK children's television. As already detailed, television was very different a quarter of a century ago, but animals are no less popular as characters.

Referring to the regular offerings of Channel 5's pre-school schedule Milkshake!, BBC's dedicated CBeebies channel, and Sony's POP channel, one can clearly see animals featuring heavily in these schedules. Few would take issue with a claim that children love animals; the city farm visits and soft toy collections of many a youngster would confirm this. However, it is also the case that the majority of children also eat animals (Shennan 2019) - an example of the now well-known concept, the 'Meat Paradox' (Loughnan, Bastian and Puvia 2012). Having extended this to species-specific 'fandom-feastdom', the 'Peppa Pig Paradox' (Korimboccus 2020), is an example of one species adorning the lunchboxes of young children whilst at the same time being contained within those lunchboxes, and shows the strength of this disconnect. Peppa Pig is one of the most popular UK children's television characters (Clement 2020), and yet food products made from pigs are the most widely-consumed in the world, the most popular red meat in the UK, and the UK's second favourite meat overall (Ritchie and Roser 2019; Shahbandeh, 2021). Children feel connected to Peppa, but remain disconnected from the source of their food (Korimboccus 2020).

The maintenance of this dissociation relies heavily on everyday discourse regarding animals. Whether identified as food, pets, wildlife or for entertainment such as zoos or circuses, TV reinforces these normative categories through stereotypical representation of animals in TV shows. Food animals, despite making up $60 \%$ of mammals and $70 \%$ of birds on our planet (Bar-On, Phillips and Milo 2018), are seldom seen in real life, and the samples in both this and Paul's (1996) study reflect that invisibility. Analysis of series featuring non-human animals as either the title or main characters provides evidence of the reinforcement of these social norms. From Peter Rabbit and Ferne and Rory's Vet Tales (CBeebies) to POP's Grizzy and the Lemmings and 44 Cats, it is clear that society and its structures are set up in a particularly speciesist way. Channels aimed at slightly older children, such as CBBC, tend to feature human characters and real human beings more heavily and non-human animals much less, and so are excluded from this analysis. 


\section{Well-'kent' Characters}

Favourite characters change with time, but some stand up to this test, such as Disney favourites Mickey and Minnie Mouse, now in their nineties, and in the UK most notably Peppa Pig, aired now for seventeen years. In reality, pigs raised for slaughter seldom make it past six months of age (Hoar and Angelos no date). Interestingly, many well-known characters are not of the species most associated with childhood companion relationships, such as dogs. Instead, they tend to be 'wild' species (such as Bugs Bunny or Donald Duck), or 'food' species (such as Miss Piggy), neither of which children are likely to have developed significant real relationships with. This, though, creates contradictory belief systems from early life. Kermit the Frog is a loved character, while real frogs are seldom-seen, at least by urban children. Shaun the Sheep seems smart enough to attempt to alleviate more than a decade of boredom (though not enough to escape the farm) while real lambs and sheep have their fate sealed within only a few months or years. It is little wonder that children do not make associations with animal use other than that imagined by and instilled through animated animal characters. In this way, the reality of 'meat' need never be addressed.

Figure 1. 'Representation of a speciesist material and discursive positioning of animals'.

A simple illustration of the categorisation of animals children learn from their surroundings. Human animals afforded full subjective sensibility are found in the north-west zone, while the south-eastern area is referred to as the 'killing zone' and is the location of animal individuals seldom seen.

(Source: Stewart and Cole 2009; Cole and Stewart 2018). Reproduced with permission.

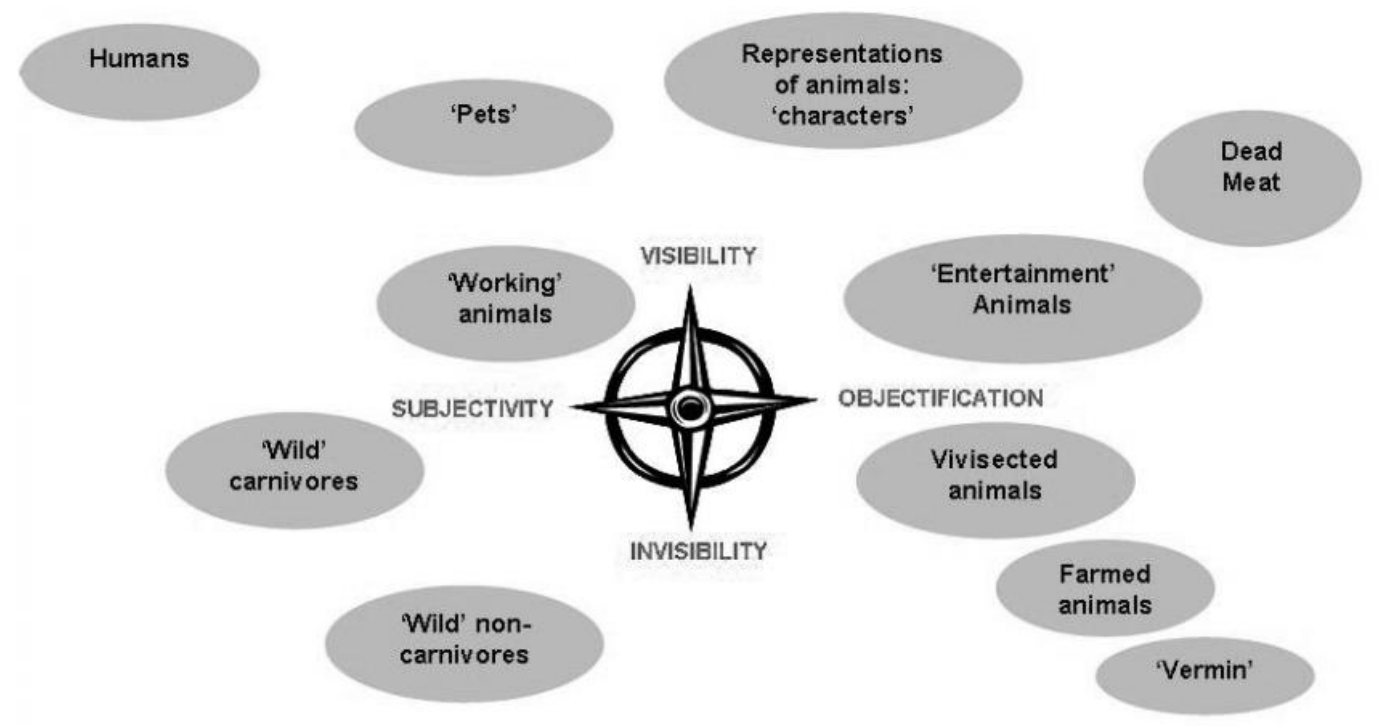

Figure 1: Representation of a speciesist material and discursive positioning of animals 
The reinforcement of these categories by mainstream media serves only to maintain normative discourse regarding the species involved. Whichever category a species finds itself in, however, all indicate the commodification of non-humans for one sort of human gain or another. Representations of animals as 'characters' are visible through the media, though often in an objectified way, as illustrated in Figure 1. Animal characters made up around one third of British Animation Awards finalist nominations in 2020, such is their prevalence and popularity (British Animation Awards 2020). Despite the UK's claim to love animals however, only those categorised as 'pets', or 'working' species - for example. dogs used to assist humans, horses raced for money - are regarded in any similar way to ourselves in everyday discourse.

\section{Methodology and Procedure}

To establish the frequency with which different categories of species are characterised through children's TV programming, a total of three hundred and fourteen programmes within five different schedules on three different days between 1 July and 17 August 2020 were considered.

Only mainstream non-subscription channels available throughout the United Kingdom were included - i.e., those available on free-to-view digital television, such as Freeview. This ensures the minimisation of socio-economic factors, where more wealthy families may be more likely to have individual subscriptions such as Disney+ or digital entertainment packages which include channels such as Disney Junior and Nickelodeon. Tiny Pop, the UK home of shows such as My Little Pony and Masha and the Bear, is also excluded as, although available on Freeview in major UK cities and their immediate surroundings, has been unavailable to most other UK locations since March 2017.

Other children's free-to-view channels such as BBC's CBBC and ITV's CITV have schedules aimed at older children, in some cases up to late teens, and overwhelmingly feature human characters, and live action rather than animation. As such, I chose to exclude these from analysis. However, some up-to-date work here would be of benefit, particularly an investigation into how and where mainstream ideology of animal use is reinforced through older children's programming.

Each date has its own numerical reference:

1. BBC CBeebies - Wednesday 1 July 2020

2. Channel 5 Milkshake! - Tuesday 11 August 2020

3. BBC CBeebies - Tuesday 11 August 2020

4. POP - Monday 17 August 2020

5. BBC CBeebies - Monday 17 August 2020

It should be noted that regional variations were not factored in as these seldom occur for the selected channels, unlike BBC and ITV's regional programming (e.g., BBC Scotland and Scottish Television (STV)).

In all, these three channels and five dates represented 66.25 hours of broadcasting. POP was the only channel transmitted twenty-four hours a day. 
BBC's CBeebies channel was included most often as it remains the most popular children's channel, despite much competition (Children's Media Foundation 2013; BAFTA 2019).

\section{Animals in Focus}

The categories of animals chosen were the most commonly represented: 'food/farm(ed)', 'pet/domesticated', and 'wild/wildlife' according to common UK utilisation of the species, and presented using the most accessible terminology for the lay reader, despite this language being somewhat speciesist.

Although focus was on lead/title characters, attention was paid to supporting characters, where relevant.

Examples of each of these categories are:

\begin{tabular}{|c|c|c|}
\hline Food/Farm(ed) & Pet/Domesticated & Wild/Wildlife \\
\hline Pig & Dog & Rabbit \\
\hline Cow & Cat & Horse \\
\hline Sheep & Rabbit & Bear \\
\hline Chicken & Fish & Fish \\
\hline Fish & Hamster & Duck \\
\hline
\end{tabular}

Some overlap is noted as many species meet two or more categories in terms of eligibility; for example, horses in domesticated and wild settings. It is observed that some non-human species may fit any one of the categories. For example, fish could be categorised as either food/farmed, pet $o r$ wild. An additional category of 'mixed' was added, where the species of two or more main characters related to different categories. Whilst several characters may also be categorised as 'entertainment' (species only visible to UK children in zoos or aquaria, for example), I retained these in the 'wild/wildlife' category as none of the programmes aired made reference to this. It should be noted, however, that past programming of CBeebies includes 64 Zoo Lane, a series relaying the evening bedtime ritual of a seven-year-old girl named Lucy who lives next to a zoo. Lucy slides down the neck of a giraffe every evening at bedtime and relies on the animals in the zoo to tell her a story, usually reminiscing about their 'wild' days, to help her get to sleep. The implication here - that these animals have been removed from the wild to become captive in an urban zoo - would likely be lost on young viewers, and perhaps even older ones. In any case, the animals make no reference to their captivity, and their presence is normalised by zoological 'collections' country-wide (Freedom for Animals no date).

Coding of the three hundred and fourteen programmes was conducted thus:

1 Programme title/lead role:

a. Non-human animal (NHA)

b. Human animal - non-human animal content (programme theme or storyline) 
c. Human animal - human animal content only, non-human animals minor/absent

d. Other (example, monsters, dragons or other fictional beings)

2 Title/lead character species category for 1(a) and 1(b):
a. NHA Food
b. NHA Pet
c. NHA Wild
d. Mixed NHAs
e. Human, but relevant animal-related content

3 Anthropomorphic traits evident in NHA characters:

a. Dress (human clothing/accessories evident)

b. Express (human facial expressions/body language evident)

c. Talk (human language as communication evident)

d. No anthropomorphic traits

Analysis was thereafter conducted on all categories other than 1(c) and (d), where human animals were the title/lead character in a programme, and the programme dealt mainly with human issues and characters. Individual programmes were included where a relevant socially normative message was expressed to the viewer through the programme's theme or its storyline - for example, children's cookery programme My World Kitchen. However, a programme where an animal was present, but in a very minor role (as a pet, for instance), was excluded.

In the interests of time, space and focus, commercial breaks were not analysed, though the marketing of animal-themed toys is commonplace, and arguably even relentless, as is the model of these species being normalised as resources for human utilisation - for example, VIP Pets.

\section{Data and Discussion}

Table 1 shows just that over four in every ten shows (41.7\%) of daily programming featured title/lead character animals, with a further $10 \%$ having transmitted more minor animal characters or animal-related content, accounting for more than half overall, or 51\%. Paul (1996) found animals a major focus of $62 \%$ of terrestrial programming for children, though one fifth of her sample was aimed at older children aged 12-16.

BBC's CBeebies channel consistently fills one third of its schedule with main animal characters, whereas Milkshake! and POP broadcast more than half a schedule of lead animal shows. However, CBeebies broadcasted a lot of other animal-themed content $(12.7 \%$ on average) whereas POP and Milkshake! add only $2.2 \%$ and $9.5 \%$ respectively. Animal-themed content here is defined as pertaining to or including animals in some way but without an animal in the title or lead role. 
Table 1. Numbers of shows with title/lead animal characters; number of shows with other title/lead characters but with animals as significant supporting cast or as the show topic; and combined totals.

\begin{tabular}{|c|c|c|c|c|c|c|c|}
\hline Ref. & Channel & Date & $\begin{array}{l}\text { Title/lead } \\
\text { animal } \\
\text { shows }\end{array}$ & $\%$ & $\begin{array}{l}\text { Other } \\
\text { relevant } \\
\text { shows }\end{array}$ & $\%$ & $\begin{array}{l}\text { Total animal } \\
\text { shows and \% } \\
\text { schedule }\end{array}$ \\
\hline 1 & CBeebies & $\begin{array}{l}\text { Wed } 1 \\
\text { Jul } 2020\end{array}$ & $23 / 68$ & 33.8 & $10 / 68$ & 14.7 & $33 / 68 \quad 48 \%$ \\
\hline 2 & $\begin{array}{l}\text { Channel } 5 \\
\text { Milkshake! }\end{array}$ & $\begin{array}{ll}\text { Tue } & 11 \\
\text { Aug } & \\
2020 & \end{array}$ & $11 / 21$ & 52.4 & $2 / 21$ & 9.5 & $13 / 21 \quad 62 \%$ \\
\hline 3 & CBeebies & $\begin{array}{ll}\text { Tue } & 11 \\
\text { Aug } & \\
2020 & \end{array}$ & $23 / 68$ & 33.8 & $8 / 68$ & 11.7 & $31 / 68 \quad 45 \%$ \\
\hline 4 & POP & $\begin{array}{ll}\text { Mon } 17 & 17 \\
\text { Aug } & \\
2020 & \end{array}$ & $51 / 90$ & 56.7 & $2 / 90$ & 2.2 & $53 / 90 \quad 59 \%$ \\
\hline 5 & CBeebies & $\begin{array}{ll}\text { Mon } 17 & 17 \\
\text { Aug } & \\
2020 & \end{array}$ & $23 / 67$ & 34.3 & $8 / 67$ & 11.9 & $31 / 67 \quad 46 \%$ \\
\hline & (All) & (All) & $131 / 314$ & 41.7 & $30 / 314$ & 9.5 & $\begin{array}{l}161 / 314 \\
51 \%\end{array}$ \\
\hline
\end{tabular}

Figure 2. Category of lead character species across main animal shows sample (repeated shows counted only once).

FIGURE 2. CHARACTER CATEGORIES

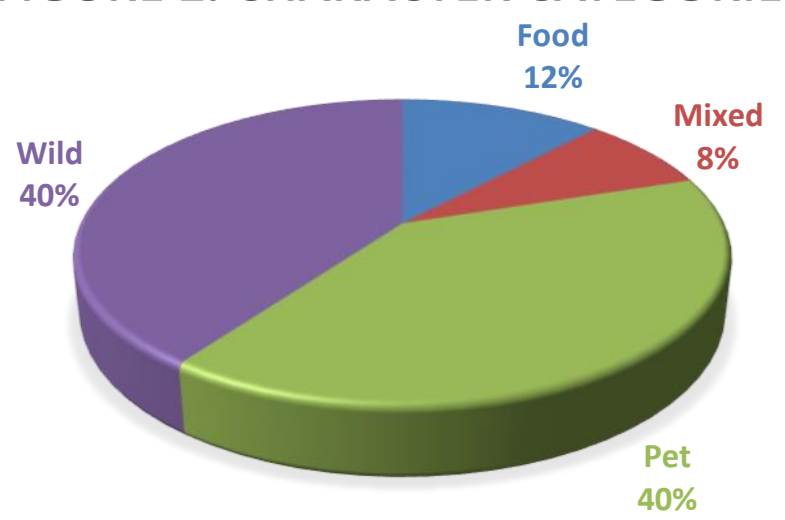


As is evident from Figure 2 above, and in line with Paul's (1996) findings, animals generally farmed for food appeared as lead characters less frequently than others at only $12 \%$, despite being the most numerous on Earth (65\% of all mammals and birds (Bar-On, Phillips and Milo 2018)). The most common species adopted as main/title characters in children's programming were either 'pets' or wildlife, with each at $40 \%$ of the sample. Paul suggested this absence of mammals, particularly as 'meat', to be 'an expression of adult society's discomfort with the paradox of advocating kindness to animals (especially mammals) on one hand, but the acceptability of meat eating on the other' $(1996,169)$. No programmes in either this or Paul's studies demonstrate the process by which animals are made into human food, nor an acknowledgement of their human utilisation.

Table 2 below focuses on characters appearing three or more times a day with a short description of the show and its main characters to summarise the content. Multiple episodes are more prevalent in the twenty-four-hour programming of POP (where not one animal related show aired only once) than the thirteen-hour schedule of CBeebies or the three hours or so of Milkshake! on Channel 5. These are significant, as repeat exposure becomes more likely, further reinforcing the characterisation of the animal to the young viewer and any anthropomorphism presented.

Table 2. Animated animal TV shows broadcasting three or more episodes per day with a short description of the show.

\begin{tabular}{|l|l|}
\hline Programme & Short description \\
\hline 44 Cats & $\begin{array}{l}\text { Four kittens who make up the band 'The Buffycats' - Lampo (lead } \\
\text { singer/guitarist), Milady (bass player), Pilou (drummer), Meatball } \\
\text { (keyboard player). They are regularly bullied by tomcat Boss and his } \\
\text { associates. }\end{array}$ \\
\hline $\begin{array}{l}\text { Alvin and the } \\
\text { Chipmunks }\end{array}$ & $\begin{array}{l}\text { Home and school antics of famous musical chipmunk trio, Alvin, Simon } \\
\text { and Theodore, and life with David Seville and neighbours (and fellow } \\
\text { entertainers) the Chipettes. }\end{array}$ \\
\hline Bing & $\begin{array}{l}\text { Bing is a young bunny spending time with his other animal friends } \\
\text { (including fellow rabbit Coco and panda Pando) and carer, Flop, also an } \\
\text { animal of indistinguishable species origin. }\end{array}$ \\
\hline $\begin{array}{l}\text { Grizzy } \\
\text { and the } \\
\text { Lemmings }\end{array}$ & $\begin{array}{l}\text { Grizzy lives in an abandoned national park ranger cabin with a group of } \\
\text { lemmings in competition for the cabin and its food, especially chocolate } \\
\text { spread. Lots of slapstick comedy ensues as they play physical pranks on } \\
\text { each other. One of the few programmes where no words are spoken. }\end{array}$ \\
\hline Hey Duggee & $\begin{array}{l}\text { Duggee is an adult dog, a scout leader of sorts for the 'Squirrels', a selection } \\
\text { of various young animals - Betty the octopus, Norrie the mouse, Roly the }\end{array}$ \\
\hline
\end{tabular}




\begin{tabular}{|l|l|}
\hline & $\begin{array}{l}\text { hippo, Tag the rhino and Happy the crocodile, as well as Enid the cat and } \\
\text { other supporting cast. }\end{array}$ \\
\hline Peppa Pig & $\begin{array}{l}\text { Young female Peppa and her family - Mummy, Daddy and little brother } \\
\text { George. Repeat support characters include Suzy Sheep, Danny Dog, } \\
\text { Rebecca Rabbit, Zoe Zebra and Pedro Pony. Peppa plays and learns about } \\
\text { the world with family and friends. }\end{array}$ \\
\hline $\begin{array}{l}\text { Talking Tom } \\
\text { and Friends }\end{array}$ & $\begin{array}{l}\text { Tom and various cat and dog friends work as inventors and adventure } \\
\text { together in and around Tom and Hank's garage. }\end{array}$ \\
\hline Timmy Time & $\begin{array}{l}\text { Timmy is a young lamb attending nursery school with other animal species } \\
\text { friends, especially best friend Yabba (a duck), and including Paxton (pig), } \\
\text { Ruffy (dog), Mittens (cat), Stripey (badger) and Apricot (hedgehog). Their } \\
\text { teachers are Harriet (a heron) and Osbourne (owl). }\end{array}$ \\
\hline
\end{tabular}

Table 2 records that an astounding nineteen separate episodes of Alvin and the Chipmunks were shown on one day, closely followed by Talking Tom and Friends at sixteen episodes. Many of these ran back-to-back with four or even five transmitted in a row. This is common practice on the POP channel. Chipmunks are rarely kept in domesticated settings in the UK, therefore it is unlikely that most children will have interacted with a real one. In any case, since 2016, it has been illegal to buy or sell a chipmunk anywhere within the European Union due to their inclusion on the 'Invasive Alien Species of Union Concern' list (RSPCA 2021). Nonetheless, Alvin and his brothers have been present in the lives of children for more than sixty years, where in reality they would be lucky to live to the age of ten, would live in the forest and hibernate each winter (Di Silvestro 2011). As with other anthropomorphised species, little of the reality of chipmunk life is evident in their characterisation on children's television.

Table 3 outlines the main character(s), their species, and species categories of all shows airing more than once per day (including those from Table 2). Most of the highest frequency programmes are shown on POP. Only one show (Waffle the Wonder Dog) features a real animal and real humans rather than animations. 
Table 3. Shows with main animal characters appearing more than once per day, by frequency.

\begin{tabular}{|c|c|c|c|c|c|}
\hline Ref. & Prog. & Freq. & $\begin{array}{l}\text { Title/lead } \\
\text { character(s) }\end{array}$ & $\begin{array}{l}\text { Character } \\
\text { species }\end{array}$ & $\begin{array}{l}\text { Species } \\
\text { category }\end{array}$ \\
\hline 4 & $\begin{array}{l}\text { Alvin and } \\
\text { the } \\
\text { Chipmunks }\end{array}$ & 19 & Alvin, Chipmunks & Chipmunk & Wild \\
\hline 4 & $\begin{array}{l}\text { Talking } \\
\text { Tom and } \\
\text { Friends }\end{array}$ & 16 & Tom, Friends & Cat, Cat/Dog & Pet \\
\hline 4 & $\begin{array}{l}\text { Grizzy and } \\
\text { the } \\
\text { Lemmings }\end{array}$ & 9 & Grizzy, Lemmings & Bear, Lemming & Wild \\
\hline 2 & Peppa Pig & 6 & Peppa & Pig & Food \\
\hline $1,3,5$ & Bing & 4 & Bing & Rabbit & Pet \\
\hline $1,3,5$ & Hey Duggee & 4 & Duggee & Dog & Pet \\
\hline 4 & 44 Cats & 3 & Cats & Cat & Pet \\
\hline $1,3,5$ & Timmy Time & 3 & Timmy & Sheep & Food \\
\hline 2 & Paw Patrol & 2 & $\begin{array}{l}\text { Chase, Rubble, } \\
\text { Rocky, Zuma, Skye }\end{array}$ & Dogs & Pet \\
\hline $1,3,5$ & $\begin{array}{l}\text { Peter } \\
\text { Rabbit }\end{array}$ & 2 & $\begin{array}{l}\text { Peter, Lily, Benjamin, } \\
\text { Mr Tod, Old Brown, } \\
\text { Tommy Brock }\end{array}$ & $\begin{array}{l}\text { Rabbits, Fox, } \\
\text { Owl, Badger }\end{array}$ & Wild \\
\hline $1,3,5$ & $\begin{array}{l}\text { Sarah and } \\
\text { Duck }\end{array}$ & 2 & Duck & Duck & Wild \\
\hline 4 & Sonic Boom & 2 & Sonic & Hedgehog & Wild \\
\hline 4 & $\begin{array}{l}\text { Space } \\
\text { Chickens in } \\
\text { Space }\end{array}$ & 2 & Space Chickens & Chickens & Food \\
\hline $1,3,5$ & $\begin{array}{l}\text { Waffle the } \\
\text { Wonder } \\
\text { Dog }\end{array}$ & 2 & Waffle & Dog & Pet \\
\hline
\end{tabular}


Table 4. Shows appearing only once per day, including short programme description.

\begin{tabular}{|c|c|c|c|c|}
\hline Ref. & Programme & $\begin{array}{l}\text { Character } \\
\text { species }\end{array}$ & $\begin{array}{l}\text { Species } \\
\text { category* }\end{array}$ & Short description \\
\hline $1,3,5$ & $\begin{array}{l}\text { Dog Loves } \\
\text { Books }\end{array}$ & Dog & Pet & $\begin{array}{l}\text { Dog loves books, mostly because of their } \\
\text { stories. He and his friend Pug are } \\
\text { transported into a different story each } \\
\text { episode. }\end{array}$ \\
\hline $1,3,5$ & $\begin{array}{l}\text { Ferne and } \\
\text { Rory's Vet } \\
\text { Tales }\end{array}$ & Any/all & Pet & $\begin{array}{l}\text { Humans Ferne Corrigan and Rory } \\
\text { Crawford are 'animal experts' who help } \\
\text { children learn what keeping animals } \\
\text { entails and how veterinarians can help if } \\
\text { the animal is sick. (the same two } \\
\text { presenters also host another show entitled } \\
\text { My Pet and Me). The first of only two } \\
\text { shows to feature real rather than animated } \\
\text { animal characters. }\end{array}$ \\
\hline $1,3,5$ & Kit and Pup & Cat/dog & Pet & $\begin{array}{l}\text { Kitten and puppy, 'Kit' and 'Pup' learn } \\
\text { about the world around them. Aimed at } \\
\text { pre-schoolers. }\end{array}$ \\
\hline $1,3,5$ & Octonauts & $\begin{array}{l}\text { Various } \\
\text { sea, cat, } \\
\text { rabbit, dog }\end{array}$ & Wild/Pet & $\begin{array}{l}\text { Led by 'Captain Barnacles' (a polar bear), } \\
\text { the underwater explorer crew consists of } \\
\text { Kwazii the cat, Peso the penguin, } \\
\text { Professor Inkling the octopus, Dr } \\
\text { Shellington the sea otter, Tweak the } \\
\text { rabbit, Dashi the dog and half-tuna, half } \\
\text { turnip 'Tunip'. They regularly rescue sea } \\
\text { creatures in need, as well as occasional } \\
\text { Creature Reports, one-minute musical } \\
\text { shorts containing facts about the species } \\
\text { rescued and their habitat. }\end{array}$ \\
\hline $1,3,5$ & $\begin{array}{l}\text { Patchwork } \\
\text { Pals }\end{array}$ & Any/all & Any/all & $\begin{array}{l}\text { Dozens of different species each live on a } \\
\text { square of a patchwork blanket and each } \\
\text { episode features a different square. A } \\
\text { young girl's voice interacts with them as } \\
\text { they work through a problem with the help } \\
\text { of surrounding patch animals. }\end{array}$ \\
\hline
\end{tabular}




\begin{tabular}{|c|c|c|c|c|}
\hline $1,3,5$ & $\begin{array}{l}\text { Raa Raa the } \\
\text { Noisy Lion }\end{array}$ & $\begin{array}{l}\text { Lion and } \\
\text { others }\end{array}$ & Wild & $\begin{array}{l}\text { Raa Raa and his friends (Topsy the } \\
\text { giraffe, Zebby the zebra, Hufty the } \\
\text { elephant, Ooo Ooo the chimpanzee, } \\
\text { Crocky the crocodile, Pia the parrot and } \\
\text { Scuttle the spider) all live in the Jingly } \\
\text { Jangly Jungle. }\end{array}$ \\
\hline $1,3,5$ & Tee and Mo & Monkey & Wild & $\begin{array}{l}\text { Mo and Tee are monkey mother and three- } \\
\text { year-old son, respectively. They have a lot } \\
\text { of fun together, though Tee is a little } \\
\text { mischievous. }\end{array}$ \\
\hline $1,3,5$ & $\begin{array}{l}\text { Tinga Tinga } \\
\text { Tales }\end{array}$ & Various & Wild & $\begin{array}{l}\text { Now more than a decade old, and based } \\
\text { on traditional African animal tales and } \\
\text { Tanzanian art, each episode is narrated by } \\
\text { 'Red Monkey' and relays animal folk } \\
\text { tales such as Why Buffalo has Horns and } \\
\text { Why Jackal Howls at the Moon. Regular } \\
\text { characters include Elephant, Lion, Hippo } \\
\text { and Tortoise. }\end{array}$ \\
\hline 2 & $\begin{array}{l}\text { Milkshake! } \\
\text { Monkey's } \\
\text { Amazing } \\
\text { Adventures }\end{array}$ & Monkey & Wild & $\begin{array}{l}\text { Puppet character 'Milkshake Monkey' } \\
\text { both features in his own shows and as a } \\
\text { Milkshake presenter. He was also to be } \\
\text { the main focus of the } 2020 \text { Milkshake } \\
\text { Live touring stage show Milkshake } \\
\text { Monkey's Musical. He, of course, loves } \\
\text { bananas. }\end{array}$ \\
\hline 2 & $\begin{array}{l}\text { Secret Life } \\
\text { of Puppies }\end{array}$ & Dog & Pet & $\begin{array}{l}\text { Documentary series on life from the } \\
\text { perspective of various individuals or } \\
\text { litters of puppies. Only the second show } \\
\text { to feature real rather than animated } \\
\text { characters. }\end{array}$ \\
\hline 2 & $\begin{array}{l}\text { Sunny } \\
\text { Bunnies }\end{array}$ & Rabbit & Wild & $\begin{array}{l}\text { Turbo, Big Boo, Iris, Shiny and Hopper } \\
\text { live on the sun. With a secret door to } \\
\text { Earth, they bring anywhere where there is } \\
\text { light to life with fun antics and play. }\end{array}$ \\
\hline
\end{tabular}


Appearing only once per day renders the significance of representation no less important. Table 4 above illustrates the eleven once-only shows of the sample where animals were the main and/or title characters. As with Table 3, only one show features real animals (Secret Life of Puppies). This may be due to the majority of young children's programming being fictional in nature. However, it has been argued that children of the target age for these programmes are unable to fully differentiate between reality and fiction (Grasso et al. 2020), so this suggests a real lack of appropriate and realistic representation, compounding already unrealistic characterisations.

\section{Anthropomorphosis}

In almost all cases, perhaps due to the sheer volume of fiction and particularly animation on offer, anthropomorphic characterisations are rife. In one of the only two cases where real dogs are lead characters (Waffle the Wonder Dog), a hoarse human voice is dubbed over his scenes to imply he is saying the words, albeit singular toddler words (however, in highlighting this, I am not necessarily suggesting a complete lack of human-centred communication ability in dogs).

To illustrate how commonplace anthropomorphic animals are in young children's TV, Figure 3 provides a breakdown of the tendency to afford human-like qualities to main animal characters, predominantly through their animation. Anthropomorphism is measured as 'Dress' (where human clothing or accessories are worn), 'Express' (where the characters express themselves in a human-like manner using facial expressions or body language), or 'Talk' (where human speech using English words is how the characters communicate).

Figure 3. Level of anthropomorphism evident in lead character species across whole main animal shows sample (repeated shows counted only once).

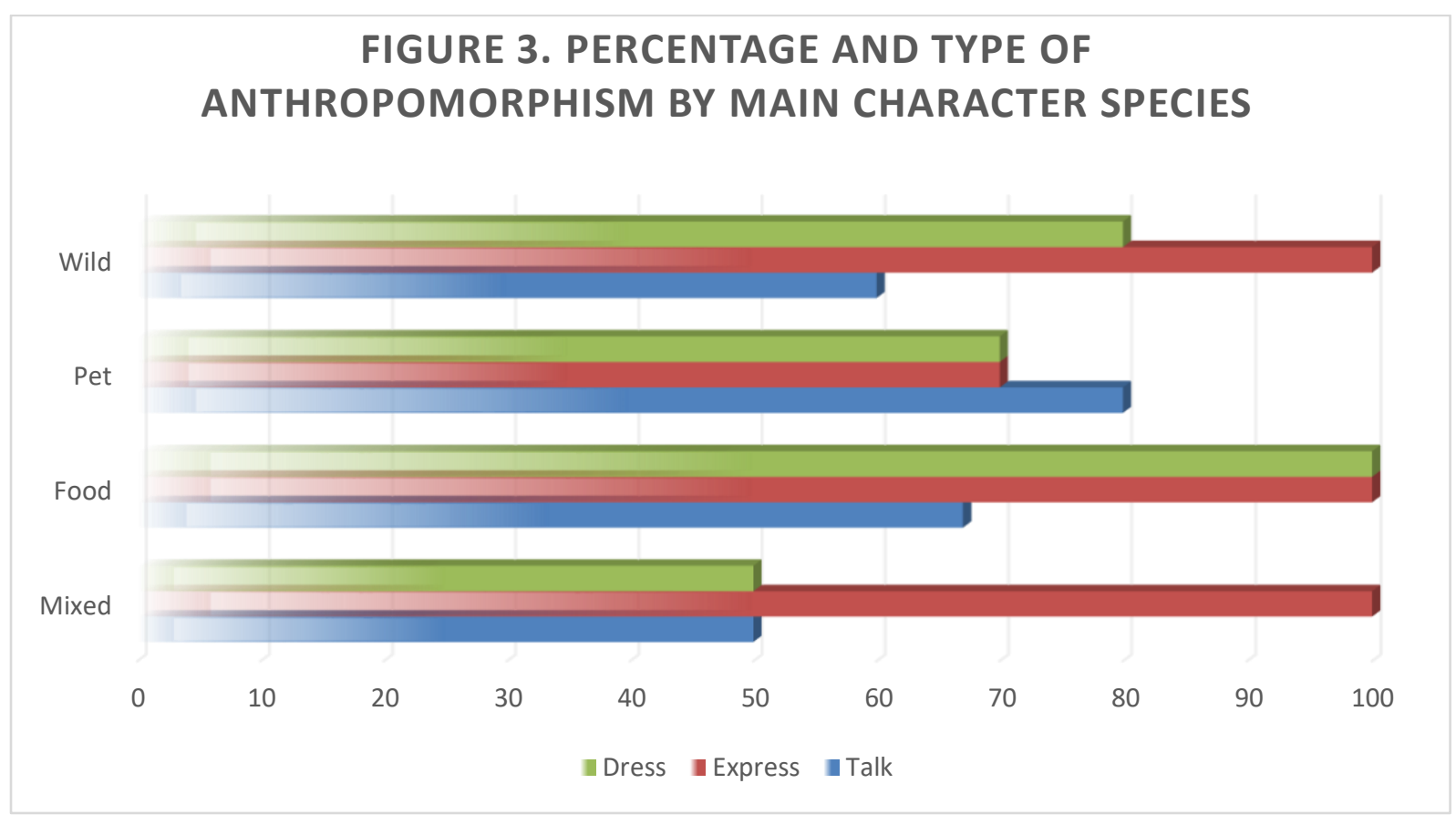


Note in Figure 3 that all main characters, except for those in the 'Pet' category, were afforded human expression, whether through facial expression, body language or both. Perhaps as surprisingly, only the 'Food' category applied human clothing or accessories to all its programmed species, though it is worth remembering (see Figure 2) that these characters were only $12 \%$ of the total sample. Speaking the same language happened both between as well as within species, so that all communicated with each other in the same way. The 'Pet' programmes with no anthropomorphic attribution were the documentary-style programmes Ferne and Rory's Vet Tales and Secret Life of Puppies. However, in both cases, the presenters afford human-like feelings and thoughts to the animals featured on the show through their narration, and at no point address the ethics involved in pet-keeping or breeding. According to Claire Parkinson, 'sites of commodification are those that are in service to capitalism where anthropomorphism is appropriated as a strategy to engage humans as customers with the "product" rather than the animal themselves' $(2019,14)$. Television provides a vehicle through which this disengagement is possible.

The use of the term 'anthropomorphism' can cause controversy, motivated by a fear that it may contribute to the breakdown of the socially normative 'food chain' hierarchy (Mills 2017) - but rightly so, when said hierarchy results in the oppression and exploitation of billions of animals. In any case, there may be value in the employment of human-like qualities to relay moral messages to children and provide an interaction, albeit two-dimensional, with species that would otherwise be impossible (Wells 2009; Geerdts, Van de Walle and LoBue 2016). However, these representations are often biased - for example, the fox and the badger in Peter Rabbit are characterised as 'baddies', and all, Peter included, are considered a 'pest' species by the human farmer. Foxes and badgers are recognisable symbols of British wildlife that adorn many a countryside calendar. At the same time, both species are often persecuted in the UK, including the ongoing murder of badgers in an attempt to deal with tuberculosis in farmed cows, or the gentrified practice of hunting foxes (though legally this can no longer be enacted using packs of dogs (League Against Cruel Sports 2021)). Norms and biases such as these are enough to maintain confusion, and not just in children.

Why, then, are most animal character animations anthropomorphic? Why use animals and not simply people? Or, if necessarily animals, why not more realistic representations of them? There are various often competing ideas about this phenomenon, including:

- Quite simply, humans, including children, are 'biologically wired' to sympathise with animals, therefore they are appropriate story characters.

- They are part of human language, thinking and story-telling - whether metaphorical or symbolic as replacement human caricature.

(Adapted from Coyne 2012)

It seems, then, that animals may be used predominantly to tell human stories, as few, if any, true-to-life representations of any species are made available, particularly not of those most likely to be in a child's life as either friend or food. Even then, wild mammals make up only $4 \%$ of species on earth (Bar-On, Phillips and Milo 2018) yet are one of the two most frequently utilised categories of animals on children's television, allowing suitable distance from reality 
to be maintained. Using animals rather than people also avoids any possibility of under- or over-representation of a particular human characteristic such as sex, ethnicity or disability, though some academics have challenged this view, believing that different species can still be reflective of the inequalities in human society (see for example Stanton 2021).

Where animals do not speak words, for example in Grizzy and the Lemmings, stereotypes are further exaggerated. Lemmings are depicted as stupid and suicidal. Humans describing other humans as 'lemmings' is a pejorative expression that suggests people incapable of independent thinking and who unquestioningly follow others. Such human-is-animal metaphors are normative, reflective of the view of each non-human animal species to the dominant social group of the human animal (Goatly 2006) - and they are often scornful.

\section{Supporting Actors}

The other shows included in Table 1 with no main animal character, but with animals as significant or in a supporting role, numbered sixteen. Several were insignificant to this study in that animals were featured, but were often extinct, as in the case of education-based reallife-meets-CGI Andy's Prehistoric Adventures or the simpler entertainment cartoons School of Roars or Kiri and Lou. Others are whimsical - for example, My Petsaurus, featuring a sevenyear-old human, Chloe, and her troublesome triceratops, Topsy. The remaining shows were analysed more thematically to help illustrate the norms relayed to children through programme content.

\section{Wild and Wonderful?}

Andy Day is CBeebies' longest-serving presenter and star of many animal-based series. In Aquatic Adventures, Andy helps viewers learn about species living in or near water, meeting them 'first-hand' through magical vehicles like his 'Safari Sub'. Andy's Safari Adventures is filmed at The Eden Project in Cornwall in the fictional 'Safari World', and Andy's Dinosaur Adventures, set in a natural history museum, sees him able to time-travel to different prehistoric periods through an old museum grandfather clock. Whilst the educational value regarding featured animals in these shows is significant, a subliminal message of the Safari Adventures show may be that safari parks and other zoological 'collections' are positive and normal, designed to conserve and protect. In reality, a minority of captive species are endangered, and even fewer reintroduced into the wild (Born Free Foundation 2007; Freedom for Animals no date).

Wild animals also featured in all three CBeebies Bedtime Stories in the sample, books often read aloud by celebrities just before the schedule closes at $7 \mathrm{pm}$. These were Leaf the Lost Polar Bear, The Busy Beaver and The Storm Bear. A quick survey of my own daughter's bookshelves likewise finds few human characters and a vast majority of non-human, 'cutified' ones (Cole and Stewart 2014). It is difficult to know whether this 'cutification' is a result of children's love of animals, or a contributor to such fondness. 


\section{Farm-Food-Fork Features}

Each spring, CBeebies broadcasts a new weekly series, Down on the Farm, in which presenters help viewers to see what happens on farms, from livestock to harvesting, as well as where food comes from and how it's grown' (Down on the Farm 2021). Each episode features some outdoor learning but also live (usually farmed) animals, including Fell ponies, Highland cows, deer, donkeys and pregnant sheep, as well as cheese and other animal product manufacture. That this is one of the few programmes to feature real animals, in real settings, being handled by real people for what it is deemed they are really 'for' may more readily capture attention. In Let's Go for a Walk, human Ranger Hamza and different children each episode (the 'Ramblers') go for a walk and learn about their surroundings, playing games along the way. During the episode 'Ponies and Pumpkins Walk', they head to the countryside and on the way, visit one of the Ranger's friend's farms, where they interact with Shetland ponies, chickens and goats with ear tags. 'The tag tells us what farm the animals belong to', says the narrator. That non-humans are considered objects of property in law is one of the key difficulties in enabling their liberation (Francione 1995).

These representations are those of the meat-eating majority. It is difficult to know at which point, if ever, children genuinely make a connection between an animal on such a show and the piece of one on their plate, particularly when 'products of violence are culturally appropriate for children but not the violence itself' (Cole and Stewart 2018, 102). Animals are presented while still alive, their purpose to humans stated - for example, 'cows give us milk/beef/leather'. Dead animals are presented as final product in other programmes. On the regular show My World Kitchen, different dishes from around the world are cooked by a child and presented to their friends at a culturally-themed lunch table, such as Series 2 Episode 12, 'Vietnamese Pork and Prawn Cha'. Rarely are the dishes completely animal-free. Shane the Chef provides another example of cookery, albeit in animated form, where Shane and his daughter Izzy run a restaurant and host an online cooking show in which many episodes feature sea animals or a vegetable such as spinach added to a recipe.

Molly and Mack is a fictional series about indoor market 'The Big Hub', located in fictional 'Bridgetown' (really North Queensferry in Fife, Scotland). Molly and Mack are siblings who, along with their father, spend their days in the market, where Mack has a stall and their father runs the Kids Club. In Series 1 Episode 9, 'Something Fishy', deliveries of fish for the harbour's fish and chip van and cakes for the indoor café are mixed up. Fish and chips (known in some areas of Scotland as a 'fish supper') is a regular meal choice of visitors to coastal towns and villages like North Queensferry. Nationally, cakes are normally (but unnecessarily) baked with eggs and dairy and other cafeteria foods contain animal ingredients, though animal-free versions are growing in availability.

\section{Animality = Superhumanity?}

Other animations focus on human characters who can transform into animal-themed superheroes, utilising the natural abilities of the relevant species as superpowers. This subtly acknowledges non-human attributes that require human activation. The most appropriate 
current example of this is POP's Miraculous Tales of Ladybug and Cat Noir (four episodes in one day). All human characters who transform into animals with the help of a totem of that animal, including the protagonist Hawk Moth or the heroes, Ladybug and Cat Noir.

When access to Tiny POP was more widespread, my own then-three-year-old daughter adored PJ Masks, a series about some young primary-age superhero children who transform into (yet again animal) superheroes by night - Owlette, Cat Boy and Gekko. That Cat Boy can jump high and Owlette has 'super owl eyes' are examples of their species-specific abilities. It is unclear whether these characters provide children with a preference for particular species of live animal in reality. Since very early childhood my daughter's favourite animal has been a duck, yet few programmes she viewed in infancy featured ducks.

\section{Old Traditions Die Hard}

Show Me, Show Me is set in a large garden where human presenters Chris and Pui pretend play as young children would do with stuffed animals, dolls and other play items such as slides and craft materials. Early in the episode 'Donkeys and Piers', real donkey Charlie joins them and various statements about him are made, such as 'donkeys are very strong and they can work very, very hard [...] plodding on and on and on [...] nodding, plodding, faithful donkey [...] being a donkey is really hard work', before the presenters help one of the toys pretend to be a donkey, saying 'here are your panniers to help carry your load'. They then repeat a rhyme, 'plod, plod, plod, plod, nodding, plodding, faithful donkey, carrying a load, following the road' as the pretend donkey offers to carry everyone's things. At one point, Pui exclaims 'your load is looking very heavy - don't drop it!' He wants to go somewhere where he can rest his hooves. Pui suggests the seaside. At the end of the show, we see a stuffed toy donkey on a beach. Although not explicit in the show, donkey rides have been associated with British seaside resorts such as Blackpool for more than a century. Children can, at a price, have a donkey walk them up and down the sand (Grand Theatre Blackpool 2019). Even talking with toy donkeys in this way reinforces the idea that donkeys are working animals for human use.

Lastly, in Sadie Sparks, Gilbert is a somewhat grumpy seven-hundred-year-old rabbit, sent from the magical realm to earth to help and guide Sadie, a young high school magician-intraining. The magical realm is contained within a top hat and again provides a sense that the use of rabbits, as well as doves and other species, in magic shows is normal, despite the potential stress this may cause to the animals (Oxley 2015).

\section{Changing Channels and Re-representations}

Many millions of animals are killed for food alone each year in the UK, and no children's programmes address this, instead providing stereotypical, anthropomorphic, 'thingified' or 'cutified' versions of various, mostly wild and pet, species. Regardless of characterisation, it is a distraction - 'children's affective imaginations are directed toward representations and away from the real victims' (Cole and Stewart 2018, 109).

It could be suggested, then, that the use of anthropomorphised animal characters on children's TV is in itself a form of animal exploitation, attracting young viewers regardless of how their 
social groups treat non-humans in reality, whose influencers establish and maintain paradoxical praxis such as that outlined in the 'Peppa Pig Paradox' (Korimboccus 2020). Adults feeding animal body parts to children whilst also encouraging them to love animals could be regarded as a disservice, and far from inclusive in terms of ethical beliefs and children's rights (Livingstone 2008).

The five schedules studied here are only a snapshot of the range of programming accessible to children, and the analysis has necessarily been a mostly descriptive one. A quick investigation of this week's offerings on CBeebies (winter 2020-21) sees a comparable breakdown of nonhuman-fronted animated programmes to last summer's sample (BBC 2021b). The 'food' animal category remains minimally present and far from realistic where it exists, though Channel 5's short Milkshake! schedule continues to air six episodes of Peppa Pig every morning between 6am and 9:15am.

The media's role in society is to convey information as objectively as possible, and this has indeed been Ofcom's view for the future of children's broadcasting for more than a decade (Ofcom 2007). As such, media must play a significant part in 'preventing or promoting social change' (Almiron 2016, 54). In pluralist terms, media might simply reflect back the norms and values, needs and wants of its consumers (Valcke, Sukosd and Picard 2016). After all, if people object to what is presented to them, they consume less or access alternatives, related income falls and a media company could find it difficult to attract inward investment to continue. Investment is very powerful, and may hold more control over content than consumers would imagine. Most media - print, digital or otherwise - relies heavily on advertising revenue, and such a revenue stream may run dry if a company's production is at moral or ethical odds with its sponsorship. The status quo is less controversial and more stable (Colistra 2014; Shoemaker and Reese 2014).

What consumers believe is important may simply be dominant ideology, taught from childhood and reinforced through these secondary agents of socialisation. Animal oppression is perpetuated through 'anthropocentric-speciesist ideology' (Almiron 2016, 65), framing the non-human as the less important 'other'. TV and other media become a site of absent reality, where 'messages about culturally appropriate relationships with nonhuman animals are transmitted in childhood in many subtle, insidious and powerful ways' (Cole and Stewart 2018, 93).

As Brett Mills (2017) notes, the representation of animals on television is a normal, everyday occurrence, and 'the animal turn', particularly in the social sciences, continues to develop with the growth in animal studies. However, attention paid to the depiction of non-humans in the mass media is negligible, and so worthy of analyses such as Mills', this article and other contributions to the growing fields of critical animal and media studies (Almiron, Cole and Freeman 2018) and vegan sociology. Akin to the feminist call for 'herstory', I suggest that vegan scholars should be calling for 'theirstory' to give animals a real voice, rather than a voiceover.

Many studies exist on the influence media has over children and young people in many areas of life such as violence, sexuality, alcohol and tobacco use, and it is reasonable to suggest that 
the same is true of attitudes to animals. Some initial work has already been undertaken into the effect television representation has on perceptions of real wild species (see for example Parkinson 2019; Grasso et al. 2020). Further research on beliefs about represented animal species on children's television, perhaps by way of audience reception research of the children themselves, would be of benefit in directly understanding how such representations affect their perceived reality of the species concerned.

Since evidence shows young children in particular find it difficult to distinguish between fiction and real life (outlined in Canadian Paediatric Society 2003), there remains a clear difficulty for producers of such programmes, as their depictions may in part be responsible for the views of children as they relate to those animals. Children receive confusing messages which may preempt paradoxes in later life - animals are lovely, our friends, our peers, and animals are food, entertainment, vermin. TV programmes contribute to normalising the exploitation of nonhuman animals for human gain by avoiding the reality of much animal life, suggesting through anthropomorphic depiction that animals are happy, and reducing the likelihood of children making connections between how they feel and what they do. This paves the way for cognitive dissonance, the Meat Paradox, and perhaps the Peppa Pig Paradox, and as such, programmes may be a vital indicator of normative belief systems requiring deconstruction before progress for animals can be made. Programme makers must be convinced that true compassion lies in inclusivity. Challenges are necessary (Almiron, Cole and Freeman 2018), including this one.

As far back as sixty-five years ago, sociologist C. Wright Mills recognised that the media's power lay in the influence of the powerful over everyday consumers, using this to perpetuate social norms and values required to maintain their social positions in a stratified system (Mills 1956). Whilst technological advances in new media see this diluted a little, and provide more (albeit limited) opportunities for formerly oppressed human groups to be heard, non-humans remain predominantly 'voiceless'. The only voices animals have on children's TV are those human ones given to them by scriptwriters and actors. As children get older, even these voices grow evermore silent, replaced with humans, their own voices and issues (Paul 1996). As long as animals are misrepresented (if represented at all) in mainstream television media, a shift in consciousness is unlikely. While television chooses to support human dominance and prevent rather than promote social change for animals, it surely remains complicit in their fate.

\section{References}

Almiron, N. (2016) 'Beyond Anthropocentrism: Critical Animal Studies and the Political Economy of Communication', The Political Economy of Communication, 4(2), pp.54-72.

Almiron, N. (2020) 'The "Animal-Based Food Taboo." Climate Change Denial and Deontological Codes in Journalism', Frontiers in Communication, 11 November. Available at: https://doi.org/10.3389/fcomm.2020.512956

Almiron, N., Cole, M. and Freeman, C.P. (2018) 'Critical Animal and Media Studies: Expanding the Understanding of Oppression in Communication Research', European Journal of Communication, 33(4), pp.367-380.

Ares, E. and Sutherland, N. (2019) Consumption of dog meat in the UK (House of Commons Library Research Briefing CDP 2019/0045). Available at: 
https://researchbriefings.files.parliament.uk/documents/CDP-2019-0045/CDP-2019-0045.pdf (Accessed: 17 September 2021).

BAFTA (2019) Children's Awards Nominations and Winners 2019 Available at: https://www.bafta.org/children/awards/childrens-awards-nominations-and-winners-2019 (Accessed: 17 September 2021).

Bar-On, Y.M., Phillips, R. and Milo, R. (2018) 'The biomass distribution on Earth', PNAS, 115(25): pp.6506-6511. Available at:

https://www.pnas.org/content/pnas/115/25/6506.full.pdf (Accessed: 17 September 2021).

BBC (2021a) Children and the BBC: From Muffin the Mule to Tinky Winky. Available at: https://www.bbc.com/historyofthebbc/research/children-and-the-bbc (Accessed: 17 September 2021).

BBC (2021b) Schedules. Available at: https://www.bbc.co.uk/schedules (Accessed: 17 September 2021).

Born Free Foundation (2007) Animal Ark or Sinking Ship? An evaluation of conservation by UK zoos. West Sussex: Born Free Foundation.

Bowd, A.D. (1982) 'Young Children's Beliefs About Animals', The Journal of Psychology, 110(2): pp.263-266.

British Animation Awards (2020) BAA 2020 Finalists Announced, 14 February. Available at: https://www.britishanimationawards.com/baa-2020-finalists-announced/ (Accessed: 17

September 2021).

Canadian Paediatric Society (2003) 'Impact of media use on children and youth'. Paediatric Child Health, 8(5), pp.301-306.

Children's Media Conference (2021) About. Available at:

https://www.thechildrensmediaconference.com/about/ (Accessed: 17 September 2021).

Children's Media Foundation (2013) BBC Trust Consultation on Children's Services.

Available at:

http://downloads.bbc.co.uk/bbctrust/assets/files/pdf/our_work/childrens_services/childrens media foundation.pdf (Accessed: 17 September 2021).

Childwise Research (2020) Childhood 2020: new independent report [Press release]. n.d. Available at:

http://www.childwise.co.uk/uploads/3/1/6/5/31656353/childwise_press_release__monitor_2020__immediate_release.pdf (Accessed: 17 September 2021).

Clement, J. (2020) Most popular children-themed YouTube channels as of May 2020, ranked by number of subscribers. Available at: https://www.statista.com/statistics/785626/mostpopular-youtube-children-channels-ranked-by-subscribers/ (Accessed: 17 September 2021).

Cole, M. and Stewart, K. (2014) Our Children and Other Animals: The Cultural Construction of Human-Animal Interaction in Childhood. London: Ashgate.

Cole, M. and Stewart, K. (2018) 'Advertising Oppression: The Reproduction of Anthroparchy in UK Children's and "Family" Television' in Matsuoka, A. and Sørenson, J. (eds.) 2018. Critical Animal Studies: Towards Trans-species Social Justice. Maryland:

Rowman \& Littlefield, pp.94-115. 
Colistra, R. (2014) 'Are Advertisers Potential (and Effective) Influencers on News Content?: An Examination of TV Reporters' Perceptions of Extramedia Pressures on Media Content and Coverage Decisions', Electronic News, 8(2), pp.83-100.

Coyne, R. (2012) 'Why cartoons have animals', Reflections on Technology, Media \& Culture, 5 May. Available at: https://richardcoyne.com/2012/05/05/why-cartoons-haveanimals/ (Accessed: 17 September 2021).

Di Silvestro, R. (2011) 'NOT Alvin and the Chipmunks: 10 Facts You May Not Know about the Real Rodents', National Wildlife Federation Blog, 13 December. Available at: https://blog.nwf.org/2011/12/not-alvin-and-the-chipmunks-10-facts-about-the-real-rodents/

Down on the Farm (2017) cBeebies. Available at: https://www.bbc.co.uk/iplayer/episodes/b0798kz4/down-on-the-farm (Accessed: 17 September 2021).

Francione, G.L. (1995) Animals, Property and the Law. Pennsylvania: Temple University Press.

Freedom for Animals (no date) The Conservation Myth: How Zoos are not Saving Endangered Species. Manchester: Freedom for Animals.

Geerdts, M.S., Van de Walle, G.A. and LoBue, V. (2016) 'Learning About real Animals From Anthopomorphic Media.' Imagination, Cognition and Pewrsonality: Consciousness in Theory, Research, and Clinical Practice, 36(1), pp.5-26.

Goatly, A. (2006) 'Humans, Animals, and Metaphors', Society \& Animals: Journal of Human-Animal Studies, 14(1), pp.15-37.

The Grand Theatre Blackpool (2019) Blackpool Donkeys - A History, 23 December. Available at: https://www.blackpoolgrand.co.uk/blackpool-donkeys-history (Accessed: 17 September 2021).

Grasso, C., Lenzi, C., Sperian, S. and Pirrone, F. (2020) 'Anthropomorphized Nonhuman Animals in Mass Media and Their Influence on Human Attitudes Toward Wildlife.' Society $\&$ Animals (published online ahead of print 2020). Available at: https://doi.org/10.1163/15685306-BJA10021

Hoar, B. and Angelos, J. (no date) Production Cycle of Swine. Western Institute for Food Safety: University of California-Davis/United States Food and Drug Administration.

Johnson, J. (2020) Household Internet Penetration in the United Kingdom (UK) 1998-2020. Available at: https://www.statista.com/statistics/275999/household-internet-penetration-ingreat-britain/ (Accessed: 17 September 2021).

Joy, M. (2009) Why We Love Dogs, Eat Pigs and Wear Cows. Conari Press.

Kondo, K. and Steemers, J. (2007) Can Television be good for Children?, London Save Kids' TV. Available at: https://westminsterresearch.westminster.ac.uk/item/91y95/can-televisionbe-good-for-children (Accessed: 17 September 2021).

Korimboccus, L.M. (2020) 'Pig-Ignorant: The Peppa Pig Paradox - Investigating Contradictory Childhood Consumption', Journal for Critical Animal Studies, 17(5), pp.3-33.

The League Against Cruel Sports (2021) Campaigns. Available at: https://www.league.org.uk/Pages/Category/campaigns?Take=18 (Accessed: 17 September 2021). 
Livingstone, S. (2008) 'On the future of children's television - a matter of crisis?', in Gardam, T. and Levy, D. A. L., (eds.) The Price of Plurality: Choice, Diversity and Broadcasting Institutions in the Digital Age. Reuters Institute for the Study of Journalism, University of Oxford: Oxford, pp. 175-182. Available at: http://eprints.lse.ac.uk/27102/ (Accessed: 17 September 2021).

Loughnan, S., Bastian, B. and Puvia, E. (2012) 'The Meat Paradox: How Are We Able to Love Animals and Love Eating Animals?', In-Mind Italia, 1, pp.15-18.

Malamud, R. (2012) An Introduction to Animals and Visual Culture. London: Palgrave Macmillan.

Matyjas, B. (2015) 'Mass media and children. Globality in everyday life', Procedia - Social and Behavioral Sciences, 174, pp.2898-2904.

Meeusen, M. (2019) 'Power, Prejudice, Predators, and Pets: Representation in Animated Animal Films' in Hermansson, C. and Zepernick, J. (eds.) The Palgrave Handbook of Children's Film \& Television. London: Palgrave Macmillan, pp.345-365.

Messenger Davies, M. and Thornham, H (2007) Academic Literature Review: The future of children's television programming. Ofcom. Available at:

https://www.ofcom.org.uk/_data/assets/pdf_file/0022/38335/litreview.pdf (Accessed: 17

September 2021).

Mills, B. (2017) Animals on Television: The Cultural Making of the Non-Human. London: Palgrave Macmillan.

Mills, C.W. (1956) The Power Elite. Reprint. Oxford: Oxford University Press, 2000.

Molloy, C. (2011) Popular Media and Animals. London: Palgrave Macmillan.

Ofcom (2019) Life on the Small Screen: What children are watching and why. A report for Ofcom. Available at: https://www.ofcom.org.uk/_data/assets/pdf_file/0021/134832/Ofcomchildrens-content-review-Publish.pdf (Accessed: 17 September 2021).

Ofcom (2020) Ofcom's Annual Report on the BBC 2019/20. Available at: https://www.ofcom.org.uk/_data/assets/pdf_file/0021/207228/third-bbc-annual-report.pdf (Accessed: 17 September 2021).

Office of National Statistics (2016) What's in the basket of goods? 70 years of shopping history. Available at: https://www.ons.gov.uk/economy/inflationandpriceindices/articles/whatsinthebasketofgoods7 0yearsofshoppinghistory/2016-07-21 (Accessed: 17 September 2021).

Oxley, J. (2015) 'The use of animals in magic shows', ISAZ 2015:Topics in Human-Animal Interactions: Significance in History and for the Future. Saratoga Springs, New York, 7-9 July. Unpublished.

Parkinson, C. (2019) Animals, Anthropomorphism and Mediated Encounters. London: Routledge.

Paul, E.S. (1996) 'The Representation of Animals on Children's Television', Anthrozoos, 9(4), pp.169-181.

Ratelle, A. (2015) Animality and Children's Literature and Film. London: Palgrave Macmillan. 
Ritchie, H. and Roser, M. (2019) 'Meat and Dairy Production', Our World in Data. Available at: https://ourworldindata.org/meat-production\#what-types-of-meat-do-people-eat (Accessed: 17 September 2021).

RSPCA (2021) Chipmunks. Available at: https://www.rspca.org.uk/adviceandwelfare/pets/rodents/chipmunks (Accessed: 17 September 2021).

Shahbandeh, M. (2021) Consumption volume of red meat in the United Kingdom (UK) in 2017, by type*. Available at: https://www.statista.com/statistics/642948/red-meatconsumption-volume-united-kingdom-uk/ (Accessed: 17 September 2021).

Shennan, R. (2019) 'One in 10 British kids are choosing not to eat meat', Edinburgh Evening News, 13 May. Available at: https://www.edinburghnews.scotsman.com/news/people/one-10british-kids-are-choosing-not-eat-meat-546905 (Accessed: 17 September 2021).

.Shoemaker, P.J. and Reese, S.D. (2014) Mediating the Message in the $21^{\text {st }}$ Century: A Media Sociology Perspective. Abingdon: Routledge.

Stanton, R.R. 2021. The Disneyfication of Animals. London: Palgrave Macmillan.

Stoll, J. (2021) Leading TV broadcasters in the United Kingdom (UK) in 2019, by audience share*. Available at: https://www.statista.com/statistics/269983/leading-tv-broadcasters-inthe-uk-by-audience-share/ (Accessed: 17 September 2021).

Strasburger, V.C. (2004) 'Children, Adolescents and the Media', Current Problems in Pediatric and Adolescent Health Care, 34(2), pp.54-113.

Stewart, K. and Cole, M. (2009) 'The conceptual separation of food and animals in childhood', Food, Culture \& Society, 12(4), pp.457-476.

The Truth about Lemmings (2021) BBC One. Available at: http://www.bbc.co.uk/earth/story/20141122-the-truth-about-lemmings (Accessed: 17 September 2021).

Valcke, P., Sukosd, M. and Picard, R., (eds.) (2016) Media Pluralism and Diversity: Concepts, Risks and Global Trends. London: Palgrave Macmillan.

Wells, P. (2009) The Animated Bestiary: Animals, Cartoons, and Culture. New Brunswick: Rutgers University Press.

YouGov (2018) The most popular channels in the UK. Available at: https://yougov.co.uk/ratings/media/popularity/tv-channels/all (Accessed: 17 September 2021).

Lynda M. Korimboccus is a passionate advocate for equity and justice. She is Programme Tutor for the Scottish Wider Access Programme (SWAP) in Social Sciences at West Lothian College, where she has worked as a lecturer in sociology for fifteen years. She is an Associate Fellow of the Higher Education Academy and an independent scholar in the field of critical animal studies. A PhD Sociology student, Lynda is researching the experiences of vegan children in Scotland with a view to making recommendations to expand the inclusivity of various institutions. Lynda also writes for Faunalytics and is Editor-in-Chief of the Student Journal of Vegan Sociology.

Email: $\underline{\text { lmkorimboccus@gmail.com }}$ 